\title{
APPLICATION OF DIFFERENT ANTI-BROWNING AGENTS IN ORDER TO PRESERVE THE QUALITY OF APPLE SLICES
}

\author{
Inta Krasnova $^{1 *}$, Inga Misina ${ }^{1}$, Dalija Seglina ${ }^{1}$, Aivars Aboltins ${ }^{2}$, Daina Karklina ${ }^{3}$ \\ I*Institute of Horticulture, Latvia University of Agriculture, Graudu iela 1, Dobele, Latvia e-mail: inta.krasnova@llu.lv \\ ${ }^{2}$ Institute of Agricultural Machinery, Latvia University of Agriculture, Cakstes bulvaris 5, Jelgava, Latvia, \\ ${ }^{3}$ Department of Food Technology, Faculty of Food Technology, Latvia University of Agriculture, Rigas iela 22, Jelgava, Latvia
}

\begin{abstract}
Apple cultivar 'Auksis' was chosen for testing in the research of anti-browning efficiency by slicing and treating them with anti-browning agents: solutions of sea buckthorn, quince and currant juices and NatureSeal ${ }^{\circledR}$ AS1. Therefore, impact of the treatment by sea buckthorn, quince and white currant diluted juice, and solution of $4 \%$ and $5 \%$ antioxidant NatureSeal ${ }^{\circledR S} 1$ on browning of fruit slices was evaluated. Strained apple slices were packed into polypropylene boxes and stored in refrigerator for 12 days at $4{ }^{\circ} \mathrm{C}$ temperature. During storage samples were analysed every third day by estimating changes in colour, content of vitamin C, total phenolic content, antioxidant activity (FRAP, DPPH). The best results of efficiency for used anti-browning agents on the quality of fresh-cut apple slices were reached by treating them with 5\% NatureSeal ${ }^{\circledR}$ AS1 solution. The selected anti-browning agent provided higher content of vitamin C, phenolic compounds, antioxidant activity (FRAP, DPPH) in the product, as well as maintained initial light colour of apple slices in comparison with other anti-browning agents.
\end{abstract}

Keywords: fresh-cut, anti-browning, colour, vitamin C, phenolics, antioxidant activity.

\section{Introduction}

In last few years supply of fresh-cut fruits in market has raised due to society's awareness of fruits potential health benefit. The polyphenolic antioxidants found in apples are responsible for most of the antioxidant activities of the fruit (Liu, 2003).

Fresh fruit browning reaction is one of the main challenges for fruit processing industry. During fruit peeling or cutting fruit cell membranes excrete cell substrate, which contains polyphenol oxidases that at the presence of oxygen dehydrogenate polyphenols to unstable hinons. These compounds are responsible in further reactions for development of dark-coloured pigments (Arias et al., 2009). To prevent browning reactions different additives could be used - ascorbic acid, citric acid, calcium propionate, calcium lactate, calcium ascorbate, carboxylic acids, chelators, thiolcontaining compounds, cysteine, glutathione or specific enzyme inhibitors such as 4-hexylresorcinol (Chiabrando, Giacalone ,2013; Rojas-Graü et al., 2006; Oms-Oliu et al., 2010; Gomesa et al., 2010). Different substances and their compositions are described as anti-browning agents for fresh-cut fruits (e.g. RojasGraï et al., 2006; Suttirak, Manurakchinakorn, 2010). Combined treatment methods are thought to be more effective (González-Aguilar, 2000).

Nowadays consumers focus not only on appearance and shelf-life of fresh-cut fruits but also are beware on synthetic additives used for colour improvement and consistency retention (Corbo et al., 2009). Therefore, impact of different natural additives instead of artificial ones against fruit browning have been studied: grapefruit seed extract (Park et al., 1999), onion extract (Kim et al., 2005), rice bran extract (Theerakulkait, Boonsiripiphat, 2007) and rosmarine extract (Xiao et al., 2010). Toivonen (2008) stated, that combined browning inhibitors NatureSeal ${ }^{\circledR}$ AS1 and AS5 could be successfully used, whereas Jeon and Zhao (2005) applied honey as anti-browning agent for freshcut apples and got good inhibition quality.
Krasnova et al. (2011) was used in experiments natural juice of cranberries (Vaccinium macrocarpon Ait) to made combinations of several browning inhibitors, which tested to provide the quality of fresh cut pear salad. There are limited data about use of natural juices to prevent this undesirable process in fresh-cut apples Perera et al. (2010) studied pineapple juice and Son et al. (2000) rhubarb juice, but for fresh cut pears slices treatment Krasnova et al. (2013) was tested Japanese quince (Chaenomeles japonica) juices dilution.

The aim of the research was to evaluate sea buckthorn (Hippophae rhamnoides L.), quince (Chaenomeles japonica), white currant (Ribes rubrum L.) juice and antioxidant NatureSeal ${ }^{\circledR}$ AS1 impact on quality of apple slices. Quality measurements were vitamin C, content of total phenols, antioxidant activity and titratable acidity as well as colour measurements.

\section{Materials and Methods}

The research has been conducted at the Processing and Biochemistry Department of the Institute of Horticulture, Latvia University of Agriculture (Formerly Latvia State Institute of Fruit-Growing) in Dobele. In this study cultivar of apples (Malus domestica L.) 'Auksis' was used. After harvesting apples were stored for one week at temperature $+4{ }^{\circ} \mathrm{C}$ and relative humidity $90 \%$.

In the present study complex inhibitors NatureSeal ${ }^{\circledR}$ AS1 (AgriCoat Ltd., Great Shefford, UK) for apple slices and NatureSeal® FS for surface of whole apples were taken. Producer AgriCoat NatureSeal ${ }^{\circledR}$ has recommended to prepare approximately $6 \%$ concentration of NatureSeal ${ }^{\circledR}$ AS1 water solution for the apple slices anti-browning treatment (AgriCoat NatureSeal ${ }^{\circledR} \quad$ Apple Protocol). Solutions of NatureSeal ${ }^{\circledR}$ AS1 (4\% and 5\%) were prepared $1 \mathrm{~h}$ before experiments. For the apple slices treatment were prepared two solutions of the NatureSeal ${ }^{\circledR}$ AS1, to find the lowest concentration of inhibitors 
NatureSeal@ AS1. Natureseal@ FS for treatment of apple surfaces were dissolved in distilled water till solution $\mathrm{pH}$ 2.4. That is recommended amount of FS which is added to water to make a solution with a $\mathrm{pH} 2.4$. This will be generally depended a 1.0-1.5\% solution concentration, but will be related on local water pH (AgriCoat NatureSeal® Protocol for Washing).

As anti-browning materials pasteurized natural sea buckthorn, quince and white currant juices were used. Sea buckthorn juice after pasteurization was left to settle down, after 24 hours clear part divided and used for experiments. Samples were treated by diluted juices. The dilution ratio was $2: 8$ (20\% juice and $80 \%$ water). The watered natural juices (concentration 20\%) was made by mixing of $20 \mathrm{~mL}$ natural juice and $80 \mathrm{~mL}$ water, following by pasteurization at temperature $95{ }^{\circ} \mathrm{C}$ and cooling till ambient temperature $20 \pm 2{ }^{\circ} \mathrm{C}$. Control sample was treated by distilled water.

Whole apples were washed in running water and whole dipped for 30 minutes in NatureSeal® FS to eliminate microbiological contamination. After that apple was peeled and cut into $1.5-2.0 \mathrm{~cm}$ slices and dipped in NatureSeal® AS1 solutions, diluted juices or distilled water (control sample) for 10 minutes, then strained on a sieve for another 10 minutes. Treated apple pieces were packed in the polypropylene boxes in air atmosphere condition, and quickly covered with lids and stored in refrigerator at temperature $+4 \pm 0.5^{\circ} \mathrm{C}$ for 12 days. Samples (in 3 replicates) were analysed after $0,3,6,9$, and 12 days.

The packaged samples were labelled as follows: Contrcontrol; SBJ-diluted sea buckthorn juice; QJ-diluted Japanese quince juice dilution; WCJ-diluted white currants juice dilution; 4NS $-4 \%$ NatureSeal ${ }^{\circledR}$ solution; $\quad 5 \mathrm{NS}-5 \% \quad$ NatureSeal ${ }^{\circledR} \quad$ solution. Accordingly, further in the paper below tables and figures will be indicated only abbreviation without a full name of the sample.

Colour characteristics (Hunter $L^{*} a^{*} b^{*}$ ) were measured for 20 apple slices using a colorimeter ColorTec-PCM BenchTop Model-45. The colour of apple flesh was expressed as whiteness index (WI), which was calculated using colour indices $\mathrm{L}^{*}, \mathrm{a}^{*}$ and $b^{*}$ as reported by Albanese et al. (2007). For determination of titratable acidity content (\% malic acid $\left.100 \mathrm{~g}^{-1}\right) 20 \mathrm{~g}$ of sample weighted and blended with $100 \mathrm{~mL}$ distilled water. $25 \mathrm{~mL}$ of filtrate were used for titration with $0.1 \mathrm{~N} \mathrm{NaOH}$ till $\mathrm{pH}$ 8.1. For the potentiometric titration $\mathrm{pH}$ meter (Jenway 3510) with combined electrode was used. The content of vitamin $\mathrm{C}$ (ascorbic acid content) was determined by the standard method EN 14130:2003 "Foodstuffs - Determination of vitamin C by HLPC". Total phenolic (TP) content was determined by the photometric method using Folin-Ciocalteau reagent by Singleton et al. (1999). The absorbance of blue colour was measured at wavelength $760 \mathrm{~nm}$. The total phenol content was expressed as gallic acid equivalent per $100 \mathrm{~g}^{-1}$ of fresh weight of apple sample (mg GAE $100 \mathrm{~g}^{-1} \mathrm{FW}$ ).
Two methods were used to measure the antioxidant activity (AOA): radical scavenging activity method using 2, 2-diphenyl-1-picrylhydrazyl (DPPH) and ferric reducing antioxidant power (FRAP) method. DPPH analysis was conducted according to BrandWilliams et al. (1995) with minor modifications. $100 \mu \mathrm{L}$ of apple extract in ethanol mixed with $2900 \mu \mathrm{L}$ of a DPPH ethanol solution. FRAP analysis was done according to Benzie and Strain (1996) with some modifications. Experiment was performed using $2700 \mu \mathrm{L}$ of FRAP reagent which was mixed with $300 \mu \mathrm{L}$ of apple extract in ethanol and incubated for $10 \mathrm{~min}$ at $20^{\circ} \mathrm{C}$. The antioxidant activity was expressed as mmol of Trolox equivalent per $100 \mathrm{~g}$ of fresh weight of apple sample (mmol TE $100 \mathrm{~g}^{-1} \mathrm{FW}$ ).

Data processing was carried out by General Linear Model procedure SPSS 15 software package. Sheffe criterion was used in the clarification of significant differences $(\mathrm{p}<0.05)$ among studied samples. Closeness of the relationship between the parameters was determined by analysis of Pearson correlation coefficient. A correlation between storage time (days), total phenol, content of vitamin $\mathrm{C}$ and antioxidant activity in fresh-cut apple sample has been found using experimental data and program MathCad package for statistical multi parametrical processing.

\section{Results and Discussion}

Colour indicators $\mathrm{L}^{*}$ value and whiteness index (WI) reflects the colour of fresh-cut apple slices equivalent (Mao et al., 2007). In addition, the L* value reflects the changes associated with the browning of apple surface ( $\mathrm{Lu}$ et al., 2007). At the beginning of the research samples of the diluted sea buckthorn juice (SBJ) showed better inhibitor properties compared to samples with quince juice (QJ) and white currant (WCJ) juices (Fig. 1 and 2). The colour of these sample after became lighter, $\mathrm{L}^{*}$ value and whiteness index were higher in comparison with the control sample, which was dipped in distilled water $(\mathrm{p}<0.05)$.

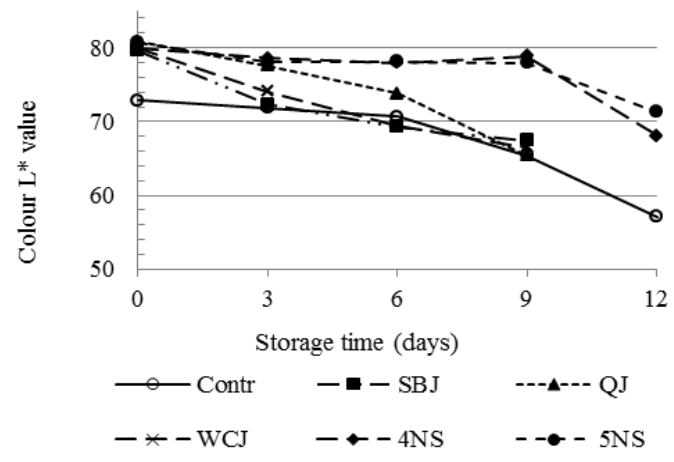

Figure 1. Changes in colour component $L^{*}$ in fresh cut apples slices during storage time

Contr - control; SBJ - diluted sea buckthorn juice; QJ - diluted Japanese quince juice dilution; WCJ - diluted white currants juice dilution; 4NS - 4\% NatureSeal ${ }^{\circledR}$ solution; 5NS - 5\% NatureSeal® solution.

Relatively good results also showed samples treated by diluted sea-buckthorn and white currant juices. $4 \%$ and 
$5 \%$ solutions of NatureSeal® AS1 showed good browning inhibitor properties compared with the control. Fresh-cut apple slices had light colour. As it was mentioned by other researchers the fastest browning of fresh-cut fruit slices proceeded in the first days that is associated with enzyme activity (PerezGago et al., 2006). During the further storage colour of samples dipped in diluted natural juices, became distinctly darker. $\mathrm{L}^{*}$ value of these samples decreased on average by $17.3 \%$ after 9 days of storage.

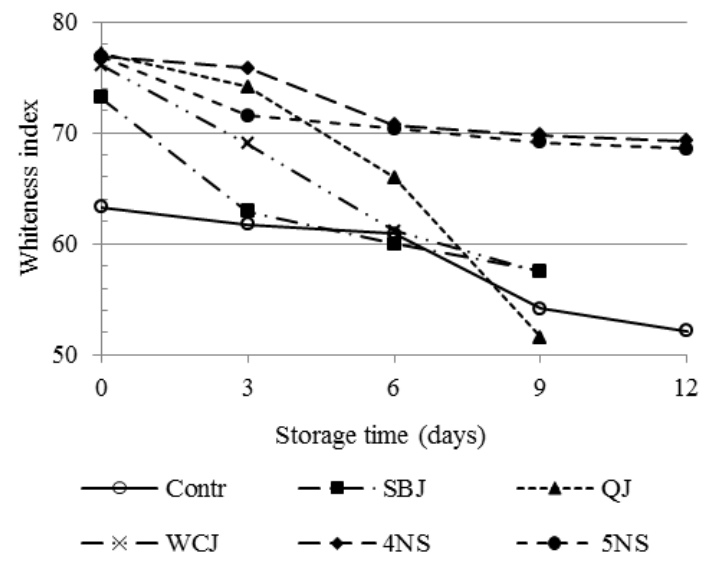

Figure 2. Changes of Whiteness index in fresh cut apples slices during storage time

Contr - control; SBJ-diluted sea buckthorn juice; QJ-diluted Japanese quince juice dilution; WCJ-diluted white currants juice dilution; 4NS - 4\% NatureSeal® solution; $5 \mathrm{NS}-5 \%$ NatureSeal® solution.

It was found that the colour intensity decreased by $10.5 \%$ in comparison to the control sample, while for samples 4NS and 5NS treated by NatureSeal ${ }^{\circledR}$ AS1 L* value reduced by only $2.2 \%$. In the last day of the study apple slices dipped in diluted natural juices were deteriorated and were not analysed. Whereas, samples $4 \mathrm{NS}$ and 5NS apple slices quality at the end of the storage time treated with the browning inhibitor NatureSeal ${ }^{\circledR}$ AS1 was retained.
At the beginning of the study titratable acidity (TA) in fresh-cut apple slices treated by diluted natural juices were on average of $1.32 \%$, for treated by NatureSeal ${ }^{\circledR}$ AS1 and $0.76 \%$ for the control sample $0.97 \%$ (Table 1). The largest decrease in TA was found in the first days, which was associated with a respiration rate of apple slices after peeling and cutting. Organic acids in combination with other compounds joined in respiratory reactions that resulted in the decreasing of acid content in fresh-cut fruits, but increasing of $\mathrm{pH}$ (Bico et al., 2009). At the ninth day of the study TA for the samples SBJ, QJ, and WCJ decreased in average of two times, but for samples 4NS and 5NS decreased slightly. In addition, the acid content on 9th and 13th day of samples dipped in NatureSeal ${ }^{\circledR}$ AS1 did not differ significantly $(\mathrm{p}=0.26)$.

Diluted natural juices were used as browning inhibitor for apple slices treated, those little increasing of the vitamin $\mathrm{C}$ content in treated samples in comparison with the control (Table 2). Complex inhibitor NatureSeal@ AS1, due to its composition ensured the highest content of vitamin $\mathrm{C}$ at the beginning of research. The significant changes of the vitamin $\mathrm{C}$ content after three days of storage were observed $(p<0.05)$. Ascorbic acid is usually degraded by oxidative processes, which are stimulated by the presence of light, oxygen, peroxides and enzymes, such as ascorbate oxidase or peroxidase (Plaza et al., 2006). After 9 days of storage, the vitamin $\mathrm{C}$ content in the samples dipped in diluted sea buckthorn juice was higher in comparison with the sample dipped in diluted quince, and white currant juices. Overall at the end of the study content of vitamin $\mathrm{C}$ was significantly higher for samples treated by NatureSeal ${ }^{\circledR}$ AS 1 in comparison with control.

Content of total phenolic (TP) was significantly $(\mathrm{p}<0.05)$ higher in the samples treated by inhibitor NatureSeal® AS1 (in average $146 \mathrm{mg}^{\circledR} 100 \mathrm{~g}^{-1} \mathrm{FW}$ ), but in samples dipped in diluted natural juices in average of 2 times less (in average $87.2 \mathrm{mg} 100 \mathrm{~g}^{-1} \mathrm{FW}$ ).

Table 1

Titratable acidity content changes in fresh cut apples slices during storage time

\begin{tabular}{lccccc}
\hline \multirow{2}{*}{ Sample } & \multicolumn{5}{c}{ Storage time, days } \\
\cline { 2 - 6 } & $\mathbf{0}$ & $\mathbf{3}$ & $\mathbf{6}$ & $\mathbf{9}$ & $\mathbf{1 2}$ \\
\hline Contr & $0.97 \pm 0.04^{*}$ & $0.77 \pm 0.01$ & $0.69 \pm 0.10$ & $0.63 \pm 0.01$ & $0.67 \pm 0.00$ \\
SBJ & $1.23 \pm 0.01$ & $0.77 \pm 0.01$ & $0.72 \pm 0.00$ & $0.71 \pm 0.01$ & ND \\
QJ & $1.37 \pm 0.01$ & $0.90 \pm 0.02$ & $0.82 \pm 0.01$ & $0.67 \pm 0.00$ & ND \\
WCJ & $1.37 \pm 0.01$ & $0.77 \pm 0.01$ & $0.62 \pm 0.00$ & $0.60 \pm 0.01$ & ND \\
4NS & $0.70 \pm 0.02$ & $0.70 \pm 0.02$ & $0.66 \pm 0.02$ & $0.63 \pm 0.01$ & $0.63 \pm 0.01$ \\
5NS & $0.81 \pm 0.05$ & $0.77 \pm 0.03$ & $0.63 \pm 0.03$ & $0.63 \pm 0.01$ & $0.60 \pm 0.02$ \\
\hline
\end{tabular}

* Titratable acidity, \%, malic acid $100 \mathrm{~g}^{-1} \mathrm{FW}, \mathrm{ND}$ - not analysed.

Table 2

Vitamin $\mathrm{C}$ content changes in fresh cut apples slices during storage time

\begin{tabular}{lccccc}
\hline \multirow{2}{*}{ Sample } & \multicolumn{3}{c}{ Storage time (days) } \\
\cline { 2 - 6 } & $\mathbf{0}$ & $\mathbf{3}$ & $\mathbf{6}$ & $\mathbf{9}$ & $\mathbf{1 2}$ \\
\hline Contr & $11.50 \pm 0.03^{*}$ & $10.73 \pm 0.37$ & $10.58 \pm 0.92$ & $7.35 \pm 0.23$ & $7.40 \pm 0.31$ \\
SBJ & $17.41 \pm 0.80$ & $12.48 \pm 0.28$ & $11.98 \pm 0.28$ & $10.27 \pm 0.62$ & ND \\
QJ & $28.46 \pm 2.12$ & $13.75 \pm 0.30$ & $10.71 \pm 0.34$ & $8.24 \pm 0.31$ & ND \\
WCJ & $11.22 \pm 0.19$ & $11.47 \pm 0.16$ & $11.30 \pm 0.46$ & $8.21 \pm 0.17$ & ND \\
4NS & $72.40 \pm 0.35$ & $49.48 \pm 0.60$ & $30.34 \pm 0.75$ & $24.09 \pm 0.32$ & $19.71 \pm 0.25$ \\
5NS & $82.35 \pm 0.36$ & $27.35 \pm 0.41$ & $30.17 \pm 1.85$ & $20.39 \pm 0.24$ & $20.34 \pm 0.17$ \\
\hline
\end{tabular}

* Vitamin C content $\mathrm{mg} 100 \mathrm{~g}^{-1} \mathrm{FW}, \mathrm{ND}$ - not analysed. 
Total phenolic (TP) content changes in fresh cut apples slices during storage time

\begin{tabular}{lccccc}
\hline \multirow{2}{*}{ Sample } & \multicolumn{5}{c}{ Storage time, days } \\
\cline { 2 - 6 } & $\mathbf{0}$ & $\mathbf{3}$ & $\mathbf{6}$ & $\mathbf{9}$ & $\mathbf{1 2}$ \\
\hline Contr & $47.37 \pm 4.71^{*}$ & $69.81 \pm 1.63$ & $85.32 \pm 2.16$ & $35.12 \pm 0.73$ & $34.77 \pm 1.61$ \\
SBJ & $88.20 \pm 6.47$ & $72.87 \pm 1.57$ & $56.70 \pm 2.51$ & $46.77 \pm 2.70$ & ND \\
QJ & $85.42 \pm 7.74$ & $79.75 \pm 4.42$ & $37.57 \pm 2.38$ & $28.51 \pm 0.38$ & ND \\
WCJ & $87.95 \pm 6.58$ & $83.28 \pm 3.98$ & $37.37 \pm 2.01$ & $33.03 \pm 1.33$ & ND \\
4NS & $229.38 \pm 6.90$ & $163.57 \pm 2.73$ & $140.73 \pm 0.59$ & $148.23 \pm 1.76$ & $148.15 \pm 4.12$ \\
5NS & $145.28 \pm 2.98$ & $144.94 \pm 2.57$ & $138.01 \pm 0.26$ & $138.33 \pm 4.10$ & $138.15 \pm 0.65$ \\
\hline
\end{tabular}

* TP content, mg gallic acid $100 \mathrm{~g}^{-1} \mathrm{FW}$; ND - not analysed.

The lowest TP content (47 mg $100 \mathrm{~g}^{-1} \mathrm{FW}$ ) was for control sample (Table 3 ).

TP content of the apple slices during storage decrease and after 9 days storage different results was observed. The sample dipped in diluted sea buckthorn juice contained two times, while the samples dipped in diluted quince and white currant juice contained in average three times less of TP. The inhibitor NatureSeal ${ }^{\circledR}$ AS1 showed the best results, and at the end of the study these samples contained a significant amount of TP. Similar results were also observed in other studies, where minimal changes in content of phenolic were observed in fresh-cut apple treated by this browning inhibitor (Rößle et al., 2009). Cocci et al. (2006) observed that there is positive correlation between ascorbic acid and content of $\mathrm{TP}$ due to reducing of ascorbic acid activity that prevents a degradation of phenolic compounds. In our case Pearson correlation coefficient between the content of vitamin $\mathrm{C}$ and $\mathrm{TP} \mathrm{r}=0.76$ was observed.

Using the free radical scavenging activity (DPPH) and the ferric reducing ability (FRAP) was applied for measurement fresh-cut apple sample antioxidant activity (AOA) (Fig 3. and 4.)

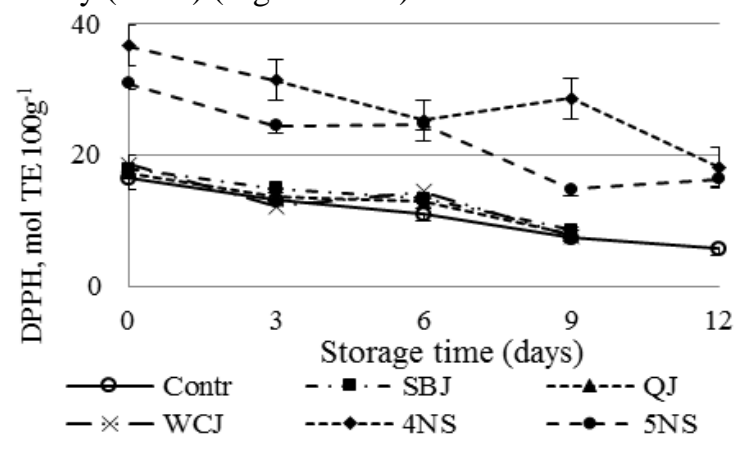

Figure 3. Antioxidant activity DPPH changes in fresh cut apples slices during storage time

Both approaches showed similar results during the study. At the first day AOA activity of all samples was significantly $(\mathrm{p}<0.5)$ higher than that of the control sample (Fig.4).

This trend continued throughout the whole period of study. It could be explained by $\mathrm{TP}$ and vitamin $\mathrm{C}$ content in the samples. A strong positive correlation between parameter of antioxidant activity there was found: between TP and AOA ( $r=0.83$ and $r=0.88)$ as well between vitamin $\mathrm{C}$ and AOA $(\mathrm{r}=0.83$ and $r=0.76$, respectively by DPPH and FRAP).

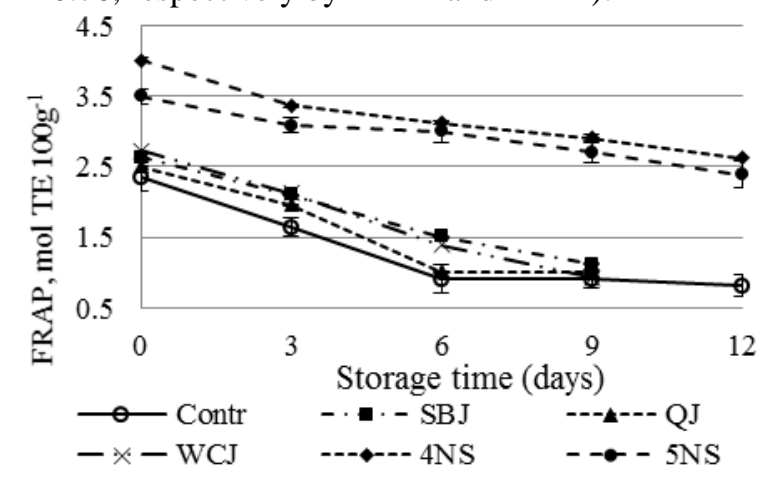

Figure 4. Antioxidant activity FRAP changes in fresh cut apples slices during storage time

As mentioned in study using pineapple, content of vitamin $\mathrm{C}$ is strongly correlating with antioxidant capacity determined by both DPPH radical scavenging activity and FRAP reducing power (Kongsuwan et al., 2009).

Antioxidant activity during storage was presumed as main evaluation quality criteria of the fresh cut apple slices after treatment by diluted juices and solution of $4 \%$ and $5 \%$ antioxidant NatureSeal ${ }^{\circledR}$ AS1 from antibrowning. Changes of the correlation between total phenolic, ascorbic acid (AA) content and antioxidant activity (FRAP) depend mostly on the storage time were found in the study.

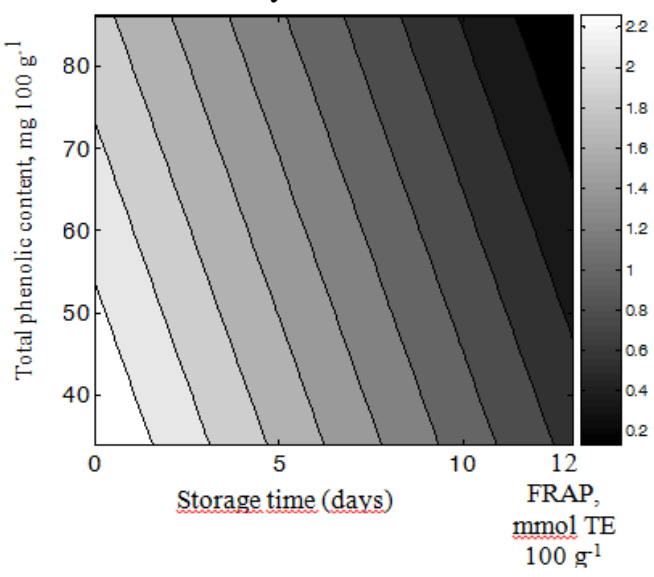

Figure 5. Changes of the correlation $\eta^{2}=0.97$ between total phenolic content and antioxidant activity (FRAP) in storage time of control sample 
The graphical interpretations of these analysed parameters in the control sample are shown in Fig. 5 and Fig. 6.

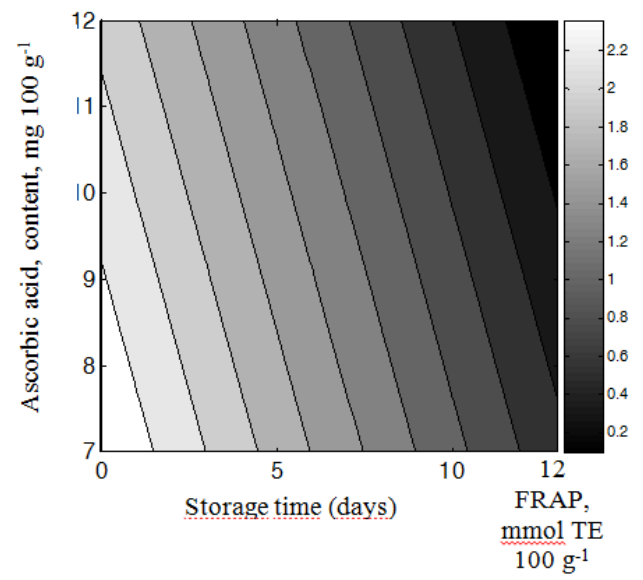

Figure 6. Changes of the correlation $\eta^{2}=0.87$ between ascorbic acid content and antioxidant activity (FRAP) in storage time of control sample

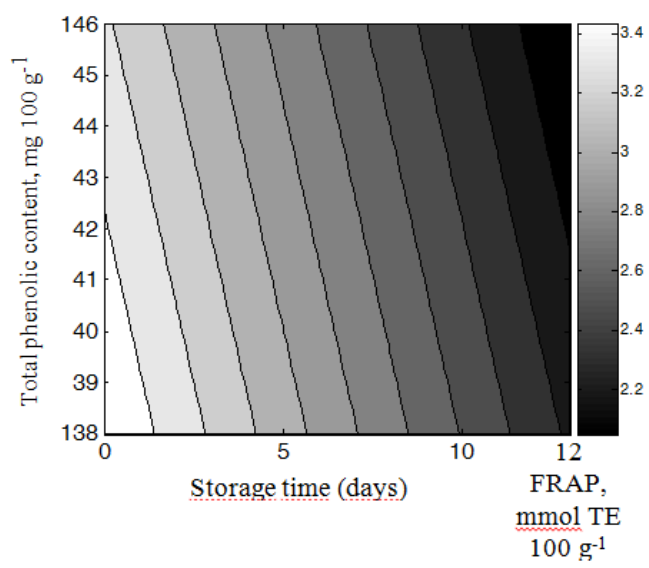

Figure 7. Changes of the correlation $\eta^{2}=0.98$ between total phenolic content and antioxidant activity (FRAP) in storage time of $5 \%$ NatureSeal ${ }^{\circledR}$ AS1 solution sample

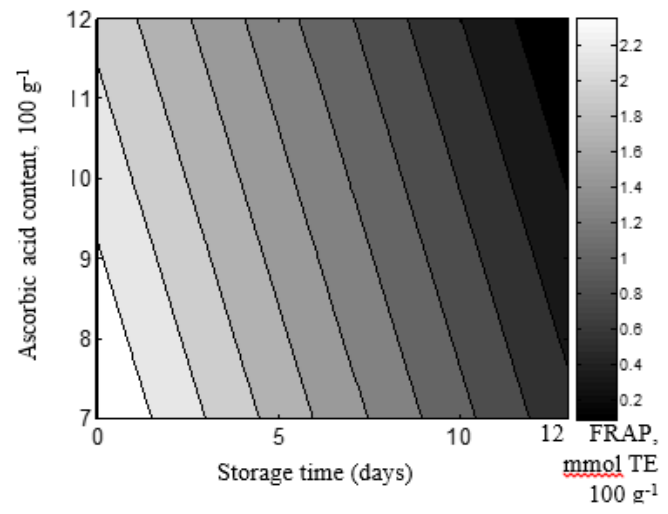

Figure 8. Changes of the correlation $\eta^{2}=0.96$

between ascorbic acid content and antioxidant activity (FRAP) in storage time on $5 \%$ NatureSeal ${ }^{\circledR}$ AS1 solution sample

The higher correlation was determined in the control sample during the storage time between total phenolic content and antioxidant activity $\left(\eta^{2}=0.97\right)$, but between ascorbic acid content and antioxidant activity (FRAP) was smaller $\left(\eta^{2}=0.87\right)$.

Very good results of the correlation between total phenolic and antioxidant activity (FRAP), ascorbic acid and antioxidant activity (FRAP) during storage time showed sample 5NS (Fig.7 and 8.). Between total phenolic content and antioxidant activity (FRAP) $\eta^{2}=0.98$ and between ascorbic acid content and antioxidant activity (FRAP) $\eta^{2}=0.96$.

\section{Conclusions}

The present study verified that the best effect on fresh-cut apple slices has 5\% solution of complex inhibitor NatureSeal ${ }^{\circledR}$ AS1. Treated samples showed the highest $\mathrm{L}^{*}$ value, content of vitamin $\mathrm{C}$ and antioxidant activity during the all storage time.

The highest total phenol content was detected in samples treated by $4 \%$ solution of NatureSeal® AS1. Using of diluted natural juices for treatment of apple slices, samples dipped in diluted quince juice had higher $\mathrm{L}^{*}$ value and contained more vitamin $\mathrm{C}$ in the first three days of storage. Superior antioxidant activity by FRAP and DPPH showed diluted white currant juice on the first day, while diluted sea buckthorn juice by DPPH on the third day of storage. In general, treatment by diluted natural juices ensured good quality of fresh-cut apple slices in the first days of storage. However, such treatments did not provide stability of samples during the all storage due to changes of quality parameters.

\section{Acknowledgment}

This research and publication has been prepared within the framework of the National Research Programme of Latvia "AgroBioRes".

\section{References}

1. Albanese D., Cinquanta, L., Di Matteo M. (2007) Effects of an innovative dipping treatment on the cold storage of minimally processed. Food Chemistry, Vol. 105, p. 1054-1060.

2. Arias E., López-Buesa P., Oria R. (2009) Extension of fresh-cut "Blanquilla" pear (Pyrus communis L.) shelflife by 1-MCP treatment after harvest. Postharvest Biology and Technology, Vol. 54, p. 53-58.

3. Benzie I.F., Strain J.J. (1996) The ferric reducing ability of plasma (FRAP) as a measure of "Antioxidant Power": the FRAP assay. Analytical Biochemistry. Vol. 239, p. 70-76.

4. Bico S.L.S., Raposo M.F.J., Morais R.M.S.C., Morais A.M.M.B. (2009) Combined effects of chemical dip and/or carrageenan coating and/or controlled atmosphere on quality of fresh-cut banana. Food Control, Vol. 20, p. 508-514.

5. Brand-Williams W., Cuvelier M.E., Berset C. (1995) Use of a free radical method to evaluate antioxidant activity. Lebensmittel - Wissenschaft und Tehnologie, Vol. 28, p. $25-30$. 
6. Chiabrando V., Giacalone G. (2013) Maintaining quality of fresh-cut apple slices using calcium ascorbate and stored under modified atmosphere. Acta Alimentaria, Vol. 42 (2), p. 245-255

7. Cocci E., Rocculi P., Romani S., Rosa M.D. (2006) Changes in nutritional properties of minimally processed apples during storage. Postharvest Biology and Technology, Vol. 39, p. 265-271.

8. Corbo M.R., Bevilacqua A., Campaniello D., D’Amato D., Speranza B., Sinigaglia M. (2009) Prolonging microbial shelf life of foods through the use of natural compounds and non-thermal approaches - a review. Intl. Journal of Food Science and Technology, Vol. 44, p. 223-241.

9. Gomes M.H., Fundo J.F., Santos S., Amaro A.L., Almeida D.P.F. (2010) Hydrogen ion concentration affects quality retention and modifies the effect of calcium additives on fresh-cut 'Rocha' pear. Postharvest Biology and Technology, Vol. 58, p. 239-246.

10. González-Aguilar G.A., Ayala-Zavala J.F., Olivas G.I., De la Rosa L.A., Álvarez-Parrilla E. (2010) Preserving quality of fresh-cut products using safe technologies. Journal für Verbraucherschutz und Lebensmittelsicherheit, Vol. 5, p. 65-72.

11. Jeon M., Zhao Y. (2005) Honey in combination with vacuum impregnation to prevent enzymatic browning of fresh-cut apples. International Journal Food Science and Nutrition, Vol. 56, p. 165-176.

Kim M.-J., Kim C.Y., Park I. (2005) Prevention of enzymatic browning of pear by onion extract. Food Chemistry, Vol. 89, p. 181-184.

12. Kongsuwan A., Suthiluk P., Theppakorn T., Srilaong V., Setha S. (2009) Bioactive compounds and antioxidant capacities of phulae and nanglae pineapple. Asian Journal of Food and Agro-Industry, Special Issue, p. $44-50$.

13. Krasnova I., Dukalska L., Seglina D., Misina I. Karklina D. (2013) Influence of anti-browning inhibitors and biodegradable packaging on the quality of fresh-cut pears. Proceedings of the Latvian Akademy of Sciences. Section B, Vol. 67 (2), p. 20-30.

14. Krasnova I., Aboltins A., Seglina D., Karklina D., Suraka V. (2011) Changes of vitamin C and polyphenols during the storage time in minimally processed pear salads with various anti-browning additions. In: The 6th International CIGR Technical Symposium, Toward a Sustainable Food Chain-Food Process, Bioprocessing \& Food quality management. Conference proceedings, Nantes: Oniris, France, p. 118-121.

15. Liu R.H. (2003) Health benefits of fruit and vegetables are from additive and synergistic combinations of phytochemicals. Amererican Journal Clinical Nutrition, Vol. 78, p. 517-520.

16. Lu S., Luo Y., Turner E., Feng H. (2007) Efficacy of sodium chlorite as an inhibitor of enzymatic browning in apple slices. Food Chemistry, Vol. 104, p. 824-829.

17. Mao L., Lu F., Wang G. (2007) Application of 1-methylcyclopropene reduces wound responses and maintains quality in fresh-cut apple. Asia Pacific Journal Clinical Nutrition, Vol. 16, p. 111-115.
18. Oms-Oliu G., Rojas-Graü M.A., González L.A., Varela P., Soliva-Fortuny R., Hernando M.I.H., Munuera I.P., Fiszman S., Martín-Belloso O. (2010) Recent approaches using chemical treatments to preserve quality of fresh-cut fruit: A review. Postharvest Biology and Technology, Vol. 57, p. 139-148.

19. Park W., Lee D., Cho S. (1999) Effect of grapefruit seed extract and antibrowning agents on the keeping quality of minimally processed vegetables. Acta Horticulturae, Vol. 483, p. 325-330.

20. Perera N., Gamage T.V., Wakeling L., Gamlath G.G.S., Versteeg C. (2010) Colour and texture of apples high pressure processed in pineapple juice. Innovative Food Science. Emerginging Technology, Vol. 11, p. 39-46.

21. Perez-Gago M.B., Serra M., Del Rio M.A. (2006) Color change of fresh-cut apples coated with whey Protein concentrate-based edible coatings Postharvest Biology and Technology, Vol. 39, p. 84-92.

22. Plaza L., Sánchez-Moreno C., Elez-Martínez P., De Ancos B., Marín-Belloso O., Cano M.P. (2006) Effect of refrigerated storage on vitamin $\mathrm{C}$ and antioxidant activity of orange juice processed by high-pressure repulsed electric fields with regard to low pasteurization. European Food Research Technology, Vol. 223, p. 487-493.

23. Rojas-Graü M.A., Sobrino-López A., Tapia M.S., MartínBelloso O. (2006) Browning inhibition in fresh-cut 'Fuji' apple slices by natural antibrowning agents. Journal Food Science, Vol. 71, p. 59-65.

24. Rößle C., Gormley T.R., Butler F. (2009) Efficacy of NatureSeal ${ }^{\circledR}$ AS1 browning inhibitor in fresh-cut fruit salads applications, with emphasis on apple wedges. Journal of Horticultural Science and Biotechnology, ISAFRUIT Special Issue, p. 62-67.

25. Singleton V.L., Orthofer R., Lamuela-Raventos R.M. (1999) Analysis of total phenols and other oxidation substrates and antioxidants by means of Folin-Ciocalteau reagent. Methods Enzymology, Vol. 299, p. 152-178.

26. Son S.M., Moon K.D., Lee C.Y. (2000) Rhubarb juice as a natural antibrowning agent. Journal Food Science, Vol. 65, p. 1288-1289.

27. Suttirak W., Manurakchinakorn S. (2010) Potential application of ascorbic acid, citric acid and oxalic acid for browning inhibition in fresh-cut fruits and vegetables. Walailak Jornal of Science Technology, Vol. 7, p. 5-14.

28. Theerakulkait C., Boonsiripiphat K. (2007) Effects of rice bran extract on browning and polyphenol oxidase activity in vegetable and fruit. Kasetsart Journal (Natural Science), Vol. 41, p. 272-278.

29. Toivonen P.M.A. (2008) Influence of harvest maturity on cut-edge browning of Granny Smith' fresh apple slices treated with anti-browning solution after cutting. $L W T$ Food Science and Technology, Vol. 41, p. 1607-1609.

30. Xiao C., Zhu L., Luo W., Song X., Deng Y. (2010) Combined action of pure oxygen pretreatment and chitosan coating incorporated with rosemary extracts on the quality of fresh-cut pears. Food Chemistry, Vol. 121, p. 1003-1009. 